УДК 664

DOI https://doi.org/10.32838/2663-5941/2020.4/31

Чижевська Л.А.

Національний університет харчових технологій

Польовик В.В.

Національний університет харчових технологій

Корецька І.Л.

Національний університет харчових технологій

\title{
УДОСКОНАЛЕННЯ ТЕХНОЛОГІЇ СУПІВ ІЗ ВИКОРИСТАННЯМ РОСЛИННОЇ СИРОВИНИ
}

У статті проаналізовано попит і стан перших страв та обтрунтовано необхідність розширення асортименту групи перших страв крем-супів шляхом удосконалення традиційної рецептури. Визначено роль правильного харчування - розробка збалансованої страви і дотримання режиму харчування. Проведено аналіз кожного інгредієнта та його технологічній вплив на технологічний процес приготування перших страв. Науково обтрунтовано та доведено позитивний вплив застосування внесених молочних інгредієнтів у рецептури інноваційних крем-супів. Ці компоненти мають суттєвий вплив на фізико-хімічні показники та технологічні системи, беруть участь у забезпеченні загального флевору страви, $i$, будучи носієм незамінних амінокислот, мають нутрієнтний склад, щзо поліпшує загальну користь виробу порівняно з аналогом. Визначення впливу молочної складової частини проводили, використовуючи модельні досліди. За результатами проведених досліджень встановлено оптимальне співвідношення вхідних інгредієнтів (пошехонський сир, плавлений сир та бринза) в інноваційній технології кре -супів. Розроблена схема виробництва крем-суп із гарбуза з додаванням різних видів сирів. Для максимального збереження корисних властивостей сирів у готовій страві запропоновано деякі види сирів не піддавати термічній обробиі. Такий технологічний прийом дає змогу отримати вдосконалену страву підвищеної харчової цінності та забезпечити ї̈ збагачення незамінними нутрієнтами. На отримані модельні структури проведено комплексне очінювання та складено профілограми якості і визначено критерії якості. Наведено результати органолептичних показників, порівняння енергетичної иінності розроблених зразків крем-супу з гарбуза та добової забезпеченості основних нутрієнтів.

Ключові слова: крем-суп, молочний складник, харчова і енергетична иінність, органолептична оиінка.

Постановка проблеми. Серед різних зовнішніх факторів, які впливають на організм людини, харчування $є$ одним із найважливіших. Правильно організоване харчування забезпечує нормальний плин процесів росту й розвитку організму, збереження здоров'я і працездатності людини. Розвиток кулінарної майстерності пов'язаний із традиціями побуту, культури і звичаями населення. Своєрідність української національної кухні виражається в переважному використанні таких продуктів, як свинина, сало, шпик, свинячий топлений жир, олія, пшеничне борошно, гриби, буряки, квасоля, гарбуз [1-4].

Життя людини так влаштоване, що вона відчуває об'єктивну потребу в харчуванні 3 моменту народження. Адже фундаментальною основою життєдіяльностілюдини є енергія, джерелом якої є речовини, які надходять 3 їжею. Відігравати роль правильного харчування їжа сама по собі не може. Правильне харчування - це збалансована їжа і режим харчування. У природі не існує продуктів, які містили б усе необхідне для людини. Тому тільки комбінація різних продуктів у щоденному раціоні забезпечує організм найбільшою кількістю потрібних речовин, в основному це стосується вітамінів і мікроелементів. Процес їх засвоєння та обміну істотно залежить від присутності інших компонентів. Для того, щоб раціонально використовувати корисні властивості продуктів, необхідно знати їх хімічний склад, спеціальні прийоми технологічної обробки, правильно складати раціон і дотримуватися сприятливого для здоров'я режиму харчування.

Сучасна наука про харчування дійшла висновку, що вкрай необхідними для нормального функціонування нашого організму є перші страви. Вони важливі для раціонального харчування, забезпечують тіло теплом і енергією, допомагають 
активізувати обмін речовин і кровообіг. Перші страви мають величезний вплив на відновлення водно-сольового балансу організму, що необхідно для контролю над артеріальним тиском. Суп містить багато мінеральних речовин і вітамінів.

Важливим аспектом оцінки меню є оцінка харчової цінності запропонованих страв. Згідно 3 рекомендаціями ВООЗ оптимальне співвідношення маси основних нутрієнтів має бути: Б:Ж:В для звичайних умов становить $1: 1: 4$, а співвідношення Сa: Mg: Р становить 1:0,5:1,5 [2].

Нині більшість науковців погоджуються, що вплив харчування на здоров'я та життєдіяльність людини подвійний. 3 одного боку, харчування $€$ одним з основних важелів, який, створюючи гармонію організму людини i навколишнього середовища, сприяє певним чином здоров'ю та здатності організму протидіяти впливу несприятливих факторів. 3 іншого боку, неправильне харчування впливає на розвиток організму, знижує його захисні сили, може бути причиною багатьох хвороб.

Індустрія громадського харчування в Україні нині перебуває на стадії розвитку - зростають як кількість закладів, так і якість обслуговування.

Ефективність діяльності будь-якого підприємства ресторанного господарства залежить від багатьох факторів, що забезпечить високу лояльність споживачів, визначення чітких стратегічних перспектив розвитку діяльності, проведення оптимальної фінансової та маркетингової діяльності. У закладах ресторанного господарства дуже популярні перші страви [5].

Перші страви збуджують апетит, підвищують секрецію залоз органів травлення. Секрецію травних залоз підвищують екстрактивні речовини рідкої основи перших страв (бульйонів, відварів), органічні кислоти (томатів, квашеної капусти, квасів, солоних огірків, сметани та ін.), смакові ароматичні речовини (цибулі, моркви, білого коріння), прянощі та приправи.

Перші страви є важливим джерелом мінеральних i біологічно активних речовин (вітамінів, мікроелементів). Вони містять велику кількість рідини і покривають потребу організму у воді на $15-25 \%[3]$.

Своїм походженням супи-пюре зобов'язані французькій кухні, у деяких кулінарних книгах їх такі називають - «французькими» [4].

Пюреподібні супи $є$ однорідною протертою масою 3 консистенцією густих вершків. Завдяки цьому супи-пюре набули найбільшого поширення в дитячому, дієтичному і лікувальному хар- чуванні, коли необхідно забезпечити механічне щадіння шлунково-кишкового тракту.

Наукові дослідження у сфері організації раціонального харчування останнім часом призвели до зміни поглядів щодо приготування та подавання різноманітних страв, зумовили підвищення їх спрямованості на збереження харчової цінності та корисності продуктів. Це своєю чергою сприяло інтенсифікації розвитку громадського харчування як невід'ємної частини народного господарства.

Через демографічні особливості, специфіку культури харчування особливим попитом серед нашого населення в закладах громадського харчування користуються гарячі, перші страви 3 використанням молочного складника, а тому визначення особливостей технологічного процесу їх приготування та подавання видається нині актуальним.

Для розширення асортименту перших страв, зокрема супів-пюре, потрібно додавати до їх складу продукти, які підвищують відсоток засвоюваності, харчову цінність, вітамінів і мінеральних речовин. Нами запропоновано до крем-супу додавати молочний складник, зокрема різні види сиру. Додаючи сир, можна збільшити енергетичну цінність, підвищити вміст білків та жирів і знизити вміст вуглеводів.

Аналіз останніх досліджень і публікацій. У процесі аналізу асортименту вивчають рецептури та технології цієї групи страв, а саме різновиди крем-супів.

Перші страви популярні серед населення країни. А особливо відома така група перших страв, як крем-супи, за своєю однорідною, кремоподібною, легкою текстурою, ніжним, легким, молочно-вершковим смаком та ароматом. Окрім того, перші страви збуджують апетит, підвищують секрецію залоз органів травлення, тому їх використовують у лікувальному, дитячому і дієтичному харчуванні [2].

Проаналізувавши останні дослідження і публікацій щодо супів-пюре, а саме «Крем-суп із гарбуза», було зроблено висновки стосовно постійного розширення асортименту такими інгредієнтами, як шрот насіння вівса, імбир, мед, кокосове молоко, використання порошку морської водорості ламінарії, різноманітні добавки рослинного походження [6-8; 10].

3 огляду на вищенаведені інформаційні фактори було зроблено висновок, що цей вид страви буде доцільно удосконалити шляхом додавання до крем-супу молочного складника, а саме сичужних видів сирів. 
Постановка завдання. Метою статті є науково-практичне обгрунтування та вдосконалення технологій перших страв на рослинній сировині 3 використанням молочного складника.

Статистичну обробку даних проводили методами дисперсійного та кореляційного аналізів із використанням комп'ютерних програм «MS Office Excel 2010» та President's Young Professionals Program (РYPP) of Liberia -2019. Аналіз профілограм проводили за рекомендаціями І.Л. Корецької [9].

Виклад основного матеріалу дослідження. Найбільш популярні супи-пюре 3 чинного Збірника рецептур зібрані 3 технологій протертих супів, відомих у міжнародній кулінарній практиці як «біски», «супи велюте», «супи-креми». Технологія приготування кожного 3 перерахованих вище видів має особливості.

Супи-пюре готують із різних видів сировини: овочів, бобових, дичини. Піддані тепловій обробці й протерті продукти розводять бульйоном або молоком і заправляють вершковим маслом. Особливістю супів-пюре $\epsilon$ те, що вони становлять однорідну масу без густого осаду.

Аналіз літератури, яка висвітлює технологію приготування крем-супів, свідчить, що досліджена можливість використання сичугових сирів для приготування крем-супів у ресторанному господарстві. Вивчення того, яку користь приносять перші страви в харчуванні, та детальний аналіз рецептури, харчової та енергетичної цінності виявили малий вміст білків та великий вміст вуглеводів у страві.

Щоб збалансувати ці показники, ми запропонували збагатити страву молочним складником, використовуючи сичужні сири. Це дасть змогу не тільки збільшити вміст білків та зменшити вміст вуглеводів, а ще й підвищити енергетичну цінність та збільшити вміст жиру, збагатити страву деякими мінеральними речовинами та вітамінами. Проаналізувавши показники якості сирів (органолептичні, мікробіологічні, фізико-хімічні, хімічний склад та фізіологічні), ми дійшли висновку, що доцільно буде збагатити страву «Крем-суп із гарбуза» за рахунок: бринзи, плавленого сиру «До обіду» та пошехонського сирів.

У процесі розробки нової технології як основну сировину ми використовували мускатний сорт гарбуз, а саме «Хоккайдо». Додавали до рецептури або бринзу, або плавлений, або пошехонський сир зі збереженням маси виходу готової страви на одну порцію. Для досягнення високих органолептичних показників ми, додаючи сири, зменшували, в першу чергу, кількість вершків, грінок пшеничних, а потім молока та гарбуза.

У результаті проведених досліджень: хімічного складу продуктів (поживні речовини, які постачають енергію і необхідні поживні речовини), фізико-хімічні показники готової страви, мікробіологічні показники для даної страви та органолептичний контроль якості готової продукції.

Ці компоненти дали змогу поліпшити консистенцію, смак і колір крем-супу, зробити його більш привабливими, ароматним та корисним.

Харчову та енергетичну цінність розраховано для дорослого населення (група II - жінки вікової групи 18-29 років) за стандартною методикою [11]. Розрахунок харчової цінності контрольного зразку та нових технологій приготування страви «Крем-супу із гарбуза» зазначено в таблиці 2.

Таблиця 1

Аналіз рецептурного складу контрольного зразку супу-пюре

\begin{tabular}{|c|c|c|c|c|c|c|}
\hline \multirow{3}{*}{ Назва продуктів } & \multirow{2}{*}{\multicolumn{2}{|c|}{$\begin{array}{c}\text { Кількість сировини } \\
\text { на } 1000 \text { г (4 порції) } \\
\text { продукції, г }\end{array}$}} & \multirow{3}{*}{$\begin{array}{l}\text { Вміст, } \\
\%\end{array}$} & \multicolumn{2}{|c|}{ Рецептурні компоненти основні } & \multirow{3}{*}{$\begin{array}{c}\text { Роль } \\
\text { у технологічному } \\
\text { процесі }\end{array}$} \\
\hline & & & & \multirow{2}{*}{$\begin{array}{c}\text { За функціональним } \\
\text { призначенням }\end{array}$} & \multirow{2}{*}{ За вмістом } & \\
\hline & Брутто & Нето & & & & \\
\hline Молоко & 400 & 400 & 100 & $\begin{array}{l}\text { Білковий, } \\
\text { казеїну, вітамінів }\end{array}$ & $\begin{array}{l}\text { Основний } \\
\text { компонент }\end{array}$ & $\begin{array}{l}\text { Основна сировина, } \\
\text { для приготування } \\
\text { страви }\end{array}$ \\
\hline Гарбуз & 571 & 400 & 16 & Вітамінний & $\begin{array}{l}\text { Основний } \\
\text { компонент }\end{array}$ & $\begin{array}{l}\text { Основна сировина, } \\
\text { для приготування } \\
\text { страви }\end{array}$ \\
\hline Масло вершкове & 20 & 20 & 100 & Жировий & $\begin{array}{l}\text { Додатковий } \\
\text { компонент }\end{array}$ & $\begin{array}{l}\text { Надає молочний } \\
\text { присмак страві }\end{array}$ \\
\hline Вершки & 50 & 50 & 100 & Білковий & $\begin{array}{l}\text { Допоміжний } \\
\text { компонент } \\
\end{array}$ & $\begin{array}{l}\text { Формування } \\
\text { виробу }\end{array}$ \\
\hline Грінки пшеничні & 10 & 10 & 100 & Вуглеводний & $\begin{array}{l}\text { Смаковий } \\
\text { компонент }\end{array}$ & $\begin{array}{l}\text { Надає страві смакові } \\
\text { властивості та ситність. }\end{array}$ \\
\hline
\end{tabular}

Власна розробка авторів 
Таблиця 2

Визначення харчової та енергетичної цінність нових крем-супів (на порцію - 250 г)

\begin{tabular}{|l|c|c|c|c|}
\hline \multirow{2}{*}{ Показники } & \multicolumn{4}{|c|}{ Основні нутрієнти } \\
\cline { 2 - 5 } & Білки, Г & Жири, Г & Вуглеводи, г & $\begin{array}{c}\text { Енергетична цінність, } \\
\text { ккал }\end{array}$ \\
\hline Контрольний зразок & 10,31 & 15,66 & 42,0 & 346,9 \\
\hline Крем-суп із гарбуза з бринзою & 13,07 & 17,38 & 37,95 & 358,7 \\
\hline Крем-суп із гарбуза з плавленим сиром & 13,59 & 17,36 & 38,45 & 360,9 \\
\hline Крем-суп із гарбуза з пошехонським сиром & 14,69 & 18,66 & 37,95 & 376,7 \\
\hline
\end{tabular}

Власна розробка авторів

Таблиця 3

Визначення співвідношення основних нутрієнтів нових крем-супів

\begin{tabular}{|l|c|c|c|c|}
\hline $\begin{array}{c}\text { Показники харчової } \\
\text { цінності }\end{array}$ & $\begin{array}{c}\text { Контрольний } \\
\text { зразок }\end{array}$ & $\begin{array}{c}\text { Крем-суп із гарбуза } \\
\text { 3 бринзою }\end{array}$ & $\begin{array}{c}\text { Крем-суп із гарбуза } \\
\text { 3 плавленим сиром }\end{array}$ & $\begin{array}{c}\text { Крем-суп із гарбуза } \\
\text { з пошехонським сиром }\end{array}$ \\
\hline Білки, г & 1,00 & 1,00 & 1,00 & 1,00 \\
\hline Жири, г & 1,518 & 1,685 & 1,683 & 1,809 \\
\hline Вуглеводи, г & 4,073 & 3,680 & 3,729 & 3,680 \\
\hline
\end{tabular}

Власна розробка авторів

Отже, порівнюючи вміст основних нутрієнтів страви, ми констатували явне збільшення кількості та збагачення продукції білками, жирами, які вплинули на підвищення енергетичної цінності, та помітили зменшення кількості вуглеводів.

У процесі порівняння перших страв, а конкретніше крем-супу 3 гарбуза за традиційною рецептурою та крем-супів із додаванням сирів, було встановлено, що рівень вмісту білка збільшився на $26,7 \%$ (з бринзою), на 31,8\% (з плавленим сиром), на $42,4 \%$ (з пошехонським сиром), але відхилення перевищує $3,0 \%$.

Вміст жиру зріс на 11\% (з бринзою), 10,9\% (з плавленим сиром), 19,2\% (з пошехонським сиром), а вмісту вуглеводів у готовій страві зменшився на 9,7\% (з бринзою), 8,5\% (з плавленим сиром), 9,7\%(3 пошехонським сиром).

Після аналізу харчової цінності нових страв та традиційної рецептури визначали енергетичну цінність розроблених крем-супів. Помічено загальне підвищення забезпеченості калорійності страви.

Формула збалансованого харчування відображає добову потребу людини в основних харчових речовинах.

Порівнявши дослідні страви, за оптимальним співвідношенням маси білків, жирів і вуглеводів, ми дійшли висновку, що близькою до контрольного зразку є страва 3 додаванням бринзи. Страви 3 додаванням плавленого та пошехонського сирів мають незначні відхилення і за жирами $(+10,98 \% \ldots+19,17 \%)$ i $\quad$ за вуглеводами $(-9,64 \% \ldots-9,64 \%)$, та отримані показники відрізняються від показників контрольного зразка.

Органолептичне оцінювання нових страв проводили ка кафедрі технології ресторанної і аюр- ведичної продукції НУХТ, в умовах технологічної лабораторії. Тільки поглянувши на страву, можна помітити, що в рецептуру додана якась нова складова частина. У процесі додавання сирів змінились всі органолептичні показники. За контрольний зразок прийнято традиційну рецептуру першої страви - «Крем-суп із гарбуза» № 166 зі «Збірника рецептур» $[11 ; 12]$.

Додавання в рецептуру сиру змінюе всі органолептичні показники (консистенцію, колір, смак, зовнішній вигляд та запах), а також покращує смакові якості шляхом збільшення ніжності консистенції готового продукту.

Отримані результати свідчать про те, що комплексний органолептичний показник якості розроблених виробів має високе значення.

Як видно з представленої діаграми, що додавання сирів у технологію приготування овочевих крем-супів покращує показники консистенції, колір і сенсорне сприйняття продукту загалом.

Для повного уявлення про біологічну цінність розроблених страв «Крем-суп із гарбуза» розраховували такі показники, як амінокислотний скор [11], та провели обгрунтування вибору лімітуючої амінокислоти, на страву-аналог та розроблені нові страви. Розрахунок амінокислотного скору та порівняльний аналіз отриманих показників біологічної цінності розробленої продукції представлено в табл. 4.

За результатами проведеного аналізу біологічної цінності було встановлено, що досліджувані страви лімітовані за вмістом незамінних амінокислот. При цьому першою і другою лімітованою амінокислотою для всіх страв є триптофан $(6,9-13,7 \%)$ і треонін $(21,8-32,1 \%)$. 


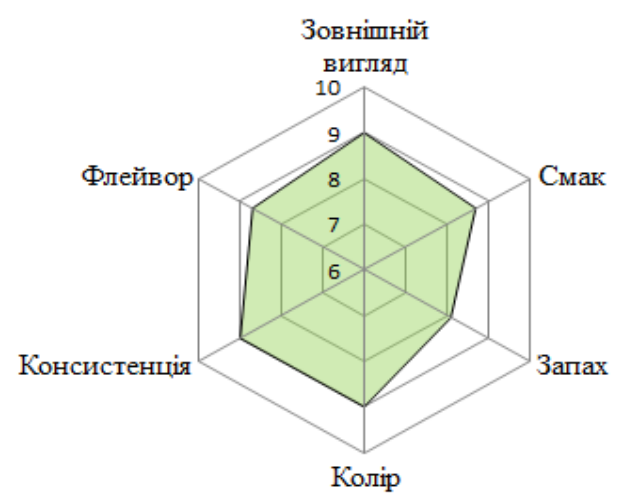

Контрольний зразок

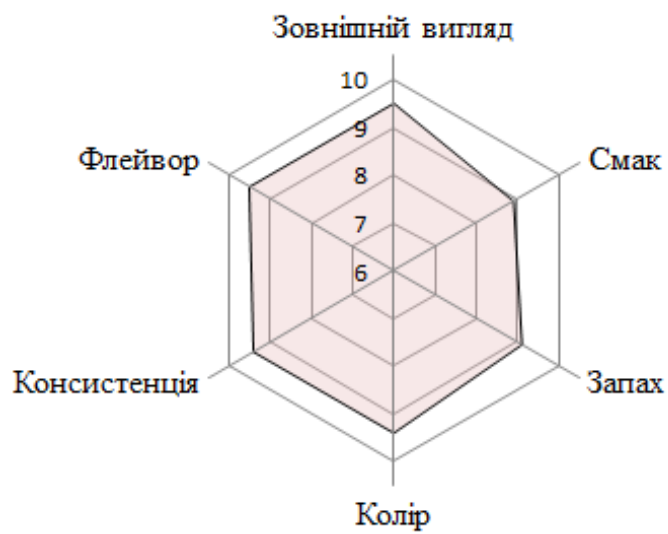

«Крем-суп із гарбуза з плавленим сиром»

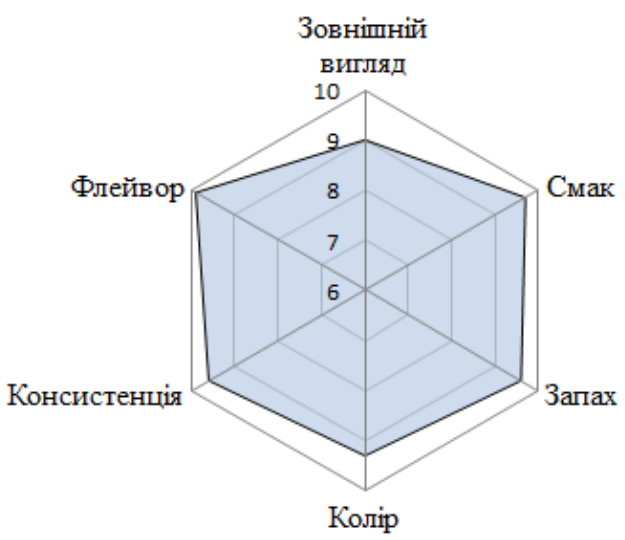

«Крем-суп із гарбуза з бринзою»

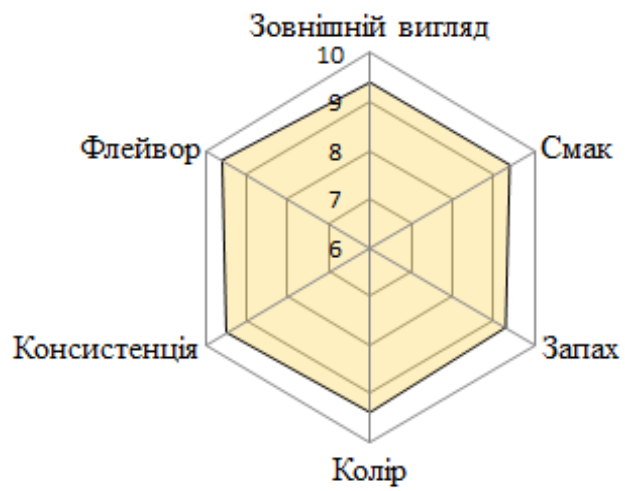

«Крем-суп із гарбуза з пошехонським сиром»

Рис. 1. Оцінка органолептичних показників

Власна розробка авторів під час дегустації страви 3 новими інгредіснтами

Таблиця 4

Ступінь задоволення добової потреби організму (на прикладі готової страви «Крем-суп із гарбуза з бринзою»)

\begin{tabular}{|c|c|c|c|c|}
\hline \multirow[b]{2}{*}{ Харчові речовини } & \multicolumn{2}{|c|}{ Вміст харчових речовин } & \multirow[b]{2}{*}{$\begin{array}{l}\text { Добова } \\
\text { потреба }\end{array}$} & \multirow[b]{2}{*}{$\begin{array}{c}\text { Ступінь } \\
\text { задоволення, \% }\end{array}$} \\
\hline & $\begin{array}{c}\text { у } 100 \text { г } \\
\text { крем-супу }\end{array}$ & $\begin{array}{c}\text { в } 1 \text { порції } \\
\text { крем-супу, 250 г }\end{array}$ & & \\
\hline \multicolumn{5}{|c|}{ Харчова та енергетична цінність } \\
\hline Білки, г & 5,227 & 13,067 & 75 & 17,42 \\
\hline Жири, г & 6,952 & 17,379 & 88,9 & 19,55 \\
\hline Вуглеводи, г & 15,181 & 37,952 & 350 & 10,84 \\
\hline $\begin{array}{l}\text { Енергетична } \\
\text { цінність, ккал }\end{array}$ & 143,48 & 358,7 & 2500 & 14,35 \\
\hline \multicolumn{5}{|c|}{ Незамінні амінокислоти, мг } \\
\hline Ізолейцин & 257,8 & 644,6 & 550 & 117,20 \\
\hline Лейцин & 419,6 & 1048,9 & 770 & 136,22 \\
\hline Лізин & 332 & 829,9 & 660 & 125,74 \\
\hline Треонін & 229,2 & 573 & 385 & 148,83 \\
\hline Триптофан & 90,4 & 225,9 & 192,5 & 117,35 \\
\hline Валін & 289,1 & 722,7 & 550 & 131,40 \\
\hline Метіонін & 114,8 & 286,9 & 715 & 40,13 \\
\hline Фенілаланін & 264,2 & 660,4 & 770 & 85,77 \\
\hline
\end{tabular}


Закінчення таблиці 4

\begin{tabular}{|c|c|c|c|c|}
\hline \multirow[b]{2}{*}{ Харчові речовини } & \multicolumn{2}{|c|}{ Вміст харчових речовин } & \multirow{2}{*}{$\begin{array}{l}\text { Добова } \\
\text { потреба }\end{array}$} & \multirow{2}{*}{$\begin{array}{c}\text { Ступінь } \\
\text { задоволення, \% }\end{array}$} \\
\hline & $\begin{array}{c}\text { у } 100 \text { г } \\
\text { крем-супу }\end{array}$ & $\begin{array}{c}\text { в } 1 \text { порції } \\
\text { крем-супу, 250 г }\end{array}$ & & \\
\hline \multicolumn{5}{|c|}{ Мінеральні речовини, мг } \\
\hline Натрій & 517,96 & 1294,9 & 4000 & 32,37 \\
\hline Калій & 210,81 & 527,03 & 4000 & 13,18 \\
\hline Кальцій & 150,81 & 377,03 & 1100 & 34,28 \\
\hline Магній & 18,68 & 46,695 & 350 & 13,34 \\
\hline Залізо & 0,46 & 1,147 & 17 & 6,75 \\
\hline Фосфор & 123,72 & 309,31 & 1200 & 25,78 \\
\hline \multicolumn{5}{|l|}{ Вітаміни, мкг } \\
\hline Вітамін А, мг & 0,06 & 0,1474 & 1000 & 0,01 \\
\hline$\beta$-каротин & 0,6 & 1,4925 & 5 & 29,85 \\
\hline Тіамин $\left(\mathrm{B}_{1}\right)$, мг & 0,07 & 0,1761 & 1,3 & 13,55 \\
\hline Рибофлавін $\left(\mathrm{B}_{2}\right)$, мг & 0,16 & 0,406 & 1,6 & 25,38 \\
\hline Нікотинова кислота (РP) & 0,42 & 1,0538 & 16 & 6,59 \\
\hline Аскорбінова кислота (C) & 4,2 & 10,51 & 70 & 15,01 \\
\hline
\end{tabular}
Власна розробка авторів

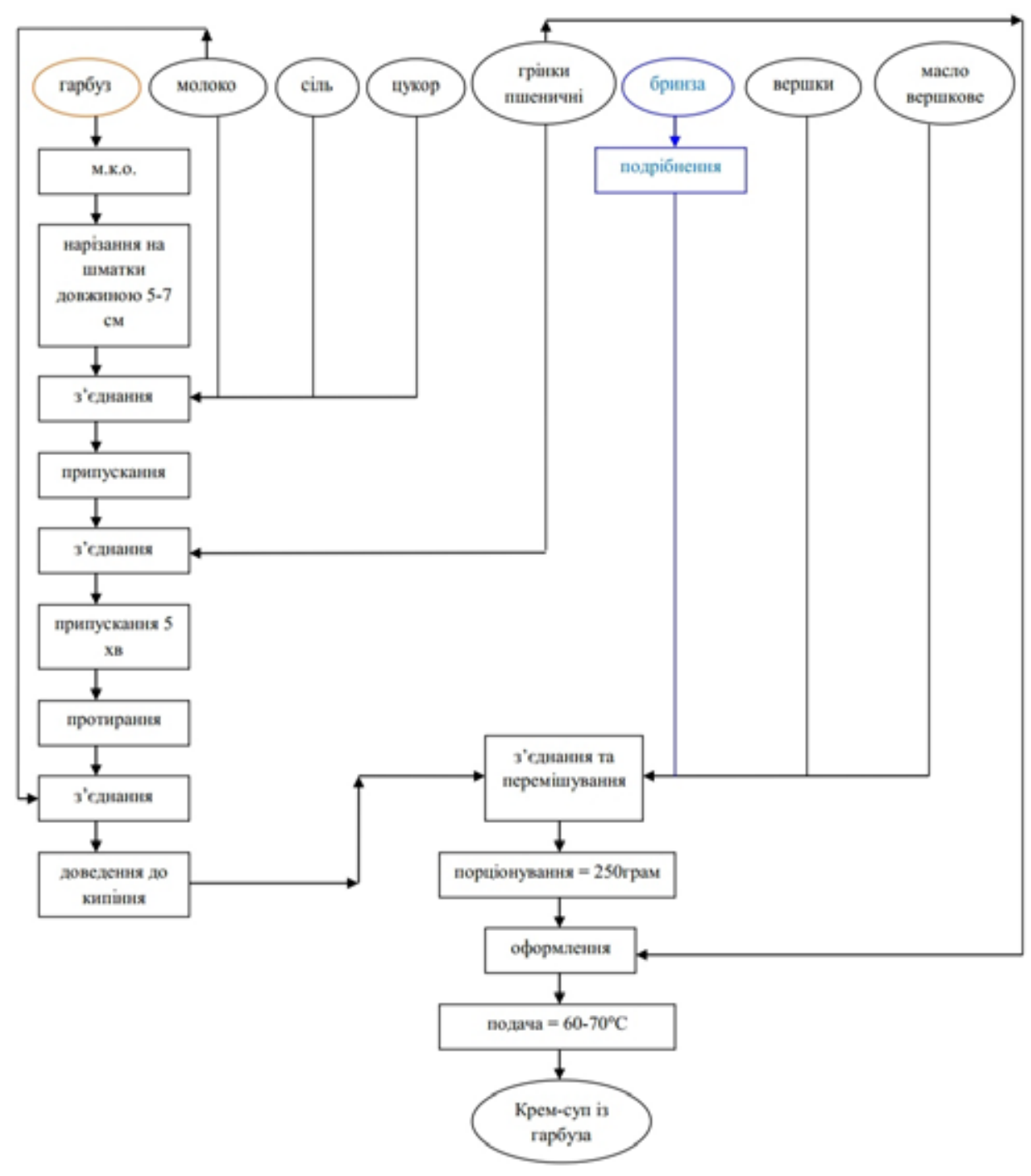

Рисунок 2. Схема технологічного процесу приготування страви «Крем-суп із гарбуза з бринзою» Власна розробка авторів 
Основна маса незамінних амінокислот вданих стравах доводиться на валін $(54,4-76,5 \%)$, метіонін (44,6-73,7\%), лейцин (44,2-61,3\%).

За показником біологічної цінності ці страви значно відрізняються, розбіжність перевищує $12-16 \%$.

Враховуючі проведені дослідження, ми розробили технологічні картки і схеми технологічного процесу приготування страв трьох найменувань крем-супу з гарбуза: «Крем-суп із гарбуза з бринзою», «Крем-суп із гарбуза з плавленим сиром», « Крем-суп із гарбуза з пошехонським сиром».

Схема технологічного процесу приготування страв «Крем-суп із гарбуза з бринзою» наведена на рис. 2.

Висновки. У процесі аналізу технології крем-супів було визначено проблемний елемент в рецептурі приготування крем-супу з гарбуза. Вирішенням цієї проблеми виявилося додавання в рецептуру страви молочного складника (різних видів сирів). 3 метою збагачення крем-супу
3 гарбуза білками, жирами як додатковий компонент у приготуванні страви використали бринзу, плавлений сир, пошехонський сир, саме його використання і стало вирішенням проблемного елементу. Завдяки молочному складнику підвищується вміст необхідних організму людини білків, жирів мікро- та макроелементів та вітамінів, амінокислот, поліненасищених жирних кислот, флавоноїдів. Страва збагачується молочними білками та жирами, зростає ії енергетична цінність, що дуже добре впливає на обмінні процеси в організмі людини, покращує травлення.

Встановлено, що отриманий продукт має поліпшені органолептичні показники та підвищену біологічну цінність, отже, ці страви можна рекомендувати для вживання людям, які страждають від виразкової хвороби шлунку і дванадцятипалої кишки, гастриту або панкреатиту, якщо перераховані недуги перебувають у стадії загострення.

Показано, що для реалізації запропонованої інновації не потрібне додаткове обладнання.

\section{Список літератури:}

1. Перші страви: користь, шкода та протипоказання. MedFond.com. URL: https://medfond.com/korysniprodukty/protipokazi-do-vzhivannya-supiv.html.

2. Шумило Г.І. Технологія приготування їжі : навчальний посібник. Київ : «Кондор». 2003. 376 с.

3. Технологія приготування їжі з основами товарознавства продовольчих товарів : підручник для проф. техн. навч. закл. / В.С. Доцяк. Частина І. Київ : Наш час, 2014. 400 с.

4. Баранов В.С., Козьмина Е.П. Технология производства продукции общественного питания. Москва : «Экономика», 1981.

5. Антонова В.А. Організація виробництва та обслуговування споживачів в закладах ресторанного господарства / Антонова В.А., Реутова М.А., Стрілець О.А., Чухраєва Л.В., Донец. нац. ун-т економіки і торгівлі ім. М. Туган-Барановського. Донецьк, 2008. 320 с.

6. Технологія функціонального крем-супу збагаченого шротом насіння вівса. URL: https://www.referat911.ru/Tehnologiya/tehnologya-funkconalnogo-kremsupu-zbagachenogo-shrotom/983681881261-place3.html. (Дата звернення 20.07.2020 p.)

7. Іваніщева О.А. Дослідження шляхів оптимізації нутрієнтного складу страв 3 гарбуза. URL: http://molodyvcheny.in.ua/files/journal/2019/4/46.pdf (Дата звернення 20.07.2020 p.)

8. Искусство готовить. Часть $1 /$ За ред. Подолюк О.О. Киев : Глобус, 2003. 270 с.

9. Koretska I, Kuzmin O., Zinchenko T. Sample rating in water-alcohol technology by profile non-linear quality criteria. Ресторанний і готельний консалтинг. Інноваиіï. 2020. Том 3, № 1 (червень). С. 12-24. URL: http://restaurant-hotel.knukim.edu.ua/issue/archive (Дата звернення 20.07.2020р.) (DOI: https://doi. org/10.31866/2616-7468.3.1.2020)

10. Левінец Ю.Д., Власенко Л.Л. Удосконалення технології приготування супів за рахунок добавки рослинного походження. URL: http://elib.hduht.edu.ua/bitstream/123456789/4652/1/t1_stud.pdf (Дата звернення 15.07.2020 p.)

11. Химический состав Российских пищевых продуктов [Текст] / Под ред. член-корр. МАИ, проф. И.М. Скурихина и академика РАМН, проф. В.А. Тутельяна. Москва, 2002. 220 с.

12. Сборник технических нормативов. Сборник рецептур блюд и кулинарных изделий для предприятий общественного питания при общеобразовательных школах / под ред. В.Т. Лапшиной. Москва : Изд. Хлебопроминформ, 2004. 417 с.

13. Сборник рецептур блюд и кулинарных изделий для предприятий общественного питания. Москва : Хлебпродинформ, 1996. 620 с. 


\section{Chyzhevsjka L.A., Polovyk V.V., Koretska I.L. IMPROVING THE TECHNOLOGY OF SOUPS WITH THE USE OF VEGETABLE RAW MATERIALS}

The article analyzes the demand and as a first course and the necessity of expanding the range of the first dishes cream soups, by improving traditional recipes. Defines the role of proper nutrition is to develop a balanced meals and adherence to diet. The analysis of each ingredient and its technological impact on the process of preparation of first courses. Scientifically demonstrated the positive impact of the use made of dairy ingredients in innovative recipes cream soups.

These components have a significant influence on the physico-chemical parameters and technological systems. Participate in the General flavor meals, and being a carrier of essential amino acids, carry a nutrient composition which improves the overall efficiency of the product in comparison with analog. To determine the influence of lactic acid was carried out using model experiments. The results of these studies determined the optimal ratio of incoming ingredients ("poshehonsky" cheese, "processed" cheese and goat cheese) in innovative technologies of cream soups. Developed a scheme of production of cream soup of pumpkin with the addition of various types of cheeses. For maximum preservation of the useful properties of cheese in the finished dish offered some kinds of cheese not subjected to heat treatment. This technological method allows to obtain an improved dish of high nutritional value and enrichment of essential nutrients. The obtained model structure underwent a comprehensive evaluation by the profilograms of the quality and defined quality criteria. The results of organoleptic indicators, comparing the energy values of the developed samples of cream of pumpkin soup and the daily supply of the main nutrients.

Key words: cream, dairy component, food and energy value, organoleptic evaluation. 